\title{
Bank Consolidation and Performance of the Nigerian Economy
}

\author{
David Ogonoye IFEGHA ${ }^{1}$ Johnson Ezema NCHEGE ${ }^{2}$ Ebikabowei Biedomo ADUKU ${ }^{3 *}$ \\ 1.Maritime University, Wari, Nigeria \\ 2.Department of Economics, University of Nigeria, Nsukka-Nigeria \\ 3.Department of Economics, Nnamdi Azikiwe University, Awka-Nigeria
}

\begin{abstract}
This study empirically examined the relationship between banks' consolidation and performance of the Nigerian economy from 1970 - 2017 using the Ordinary Least Square (OLS) technique. The findings revealed that Banks' consolidation in Nigeria had a significant impact on the performance of the economy. Banks' consolidation significantly facilitates and promotes banks' credit to the economy and economic growth in Nigeria. The economy had performed better in the post-consolidation era than the pre-consolidation era. It is recommended that consolidation policy should be carried out periodically.
\end{abstract}

Keywords: Banks Consolidation, banks' credit, Nigerian Economy

DOI: $10.7176 / \mathrm{JESD} / 10-10-03$

Publication date:May $31^{\text {st }} 2019$

\section{Introduction}

The prospect of reducing poverty is associated with every well-performing economy. A performing economy has a higher production capacity for goods and services and creates jobs and income for the people (Ohale and Onyema, 2002). This is an effective way to achieve higher living standards and economic power and prestige. An efficient financial system or intermediation process is very important in the economic growth process. It increases the level of savings and investment in the economy. This is called the quantity effect of financial intermediation. It also increases the productive capacity of the economy through greater financial deepening and increase in investment coming partly from increase savings. This is known as the quality effect of the financial system or intermediation (Waheed, 2009). Three types of services provided by a functioning financial system to the rest of the economy, which aids the economic growth process are credit provision; liquidity provision; and risk management services.

Credit provision by the financial system aids the transformation of savings from surplus sectors to deficit sectors. The relevance of this is that the credit conditions affect economic growth through investment. Liquidity provision, on the other hand, influences the direct transaction cost of going into an investment and getting out of the investment. It also affects the time taken to carry out a transaction, potentially pushing purchases or sales to be spread over days or weeks. Whereas, risk management services by functioning financial institutions serve as an edge for businesses and individuals against many forms of financial risk (Baily and Elliott, 2013). Banking sector consolidation must not be taken for granted in the pursuit of a functioning financial system, especially as financial institutions become more competitive and resilient to shocks.

Corporate restructuring and operations are products of bank consolidation that curb challenges of the global banking system. Bank consolidation liberalizes banking business, guaranteeing competition and safety of the system, mobilizes savings, expand the capital base and effectively putting the banking system in order to perform the expected financial intermediation role that paves the way for economic growth and development (CBN, 2004; and Balogun, 2007).

The Nigerian banking sector before 2005, according to Adeyemi (2006) had very small-sized fringe banks with very high overhead costs; the capital base was very low with an average of less than N1.4 billion; depends heavily on government patronage; insolvency problems and persistent illiquidity; poor asset quality; and unprofitable operations among others. These led to the introduction of the 2005 banks recapitalization policy, which all deposit money banks were required to raise a minimum paid-up capital of N25 billion. In 2009, the Central Bank of Nigeria (CBN) put in N620 billion of liquidity into the banking sector, while the Asset Management Corporation of Nigerian (AMCON) Bill was passed into law by Nigeria's National Assembly (Sanusi 2010, Anyanwu, 2010 and Iganiga, 2010). Resulting from the banking sector reforms in Nigeria, 89 deposit money banks through mergers and acquisition or shut down of operations were reduced to 25 banks as at 2006. This was due to the inability of the banks to meet up the minimum capital requirement of N25 billion. At as April 2018, the number of deposit money banks was 22 .

The reasons for these reforms were to ensure efficiency in resource allocation through market liberalization, expansion of the capital base of banks, mobilize savings and stimulate domestic investment and growth through market-based interest rates. Also, is to ensure efficiency in regulatory and surveillance framework for banks, promote healthy competition among banks in the provision of services and to entrust public confidence in the banking system, and lay the basis for inflation control and economic growth (Omoruyi 1991, CBN 2009, and Balogun 2007). 
It is worrisome that despite the consolidation, the thrust for baking sector reform is not yet actualized. Banks in Nigeria still run into liquidity problems. Nigeria's banking sector compared to most other banking sectors such as in South Africa and Yugoslavia is still below the optimal level. Nigeria is on the path to fully restore confidence in the banking sector. Efficiency in financial intermediation in the banking sector is also below expectation as well as its quantity effect (increase in savings and investment) and quality effect (increase in productivity) on the economy. There is no widespread access to bank credit and are relatively difficult for entrepreneurs to get a loan for investment. There is a need to compare the performance of the Nigerian economy before and after the bank's recapitalization policy in 2005, which is the most efficient banking sector policy in Nigeria over the years. This, therefore, forms the basis for the study, specifically focusing on the impact of bank consolidation on deposit money banks' credit to the Nigerian economy as well as the impact of bank consolidation on economic growth in Nigeria. The study would provide an insight into how the banking subsector performed before and after bank consolidation in Nigeria. It would also provide a basis for future bank consolidation policy decisions by the banking sector regulatory authority. This paper is divided into five sections. Section two follows section one, which is set aside for the review of the literature. Section three is the methodology of this study, while section four presents the results of the study. The study is rounded off in section five with policy recommendations also provided in the section.

\section{Literature Review}

\subsection{Theoretical Issues}

\subsubsection{The Concepts of Bank Consolidation and Economic Performance}

Bank consolidation is a strategic decision through which banks combine or acquire assets to raise a minimum required a capital base. It can also be described as the obligation by law for banks to raise a minimum capital requirement. Joshua (2010) classified consolidation into Mergers and acquisitions. A merger, as defined by him, is the coming together of two or more firms to become one big firm while the acquisition is the takeover or purchase of a small firm by a big firm; which are both pursuing similar motives. On the other hand, Economic performance is an increase in the performance of major sector of the economy such as the banking sector; increase in credit to the economy, which propels investment; as well as higher economic growth rates.

The link between bank consolidation and the performance of the economy is on the bases that bank consolidation will improve the banking sector performance by ensuring competition and safety of the system; expansion of the capital base; and mobilization of savings. There will be more resources needed to allocate capital; favourable return-risk combinations for savers; raise capital productivity liquidity and the allocation of risks. The provision of liquidity creates incentives to invest a larger share of savings in long-term projects which affects the performance of the economy positively.

\subsubsection{The Information Asymmetries Argument}

The "Information asymmetry" concerns bank/borrower and the bank/lender relationship. The borrower may have better knowledge than the lender as regards the risks of a project for which funds are given. The outcome of this could mostly be a moral hazard and adverse selection that could reduce the efficiency of the transfer of funds from surplus to deficit units in the economy. The idea is that the surplus unit (savers - depositors and other creditors) may not have time and inclination or expertise to monitor institutional borrowers for default risk. For this reason, the surplus unit uses indirect financing (rather than direct financing) through efficient financial intermediaries. However, the information giving by the monitor may not be sufficient and reliable, and the monitor must have incentives to perform efficiently (Gwilym, 2011). Information regarding a borrower is usually obtained by banks before and after a loan is granted. This is in addition to screening the loan applications and find out creditworthiness of the borrower and ensures that the terms of the contract are met (Gwilym, 2011). For direct financing, the borrower has to provide reliable information to prospective investors/lenders. This provides a means to solving the information asymmetry problems in subsequent direct financing.

\subsubsection{The Theory of Bank Runs}

Bank runs could be defined as sudden great demand or withdrawals on a bank. The source of potential fragility of banks include deposits, which are open to the possibility that a great number of depositors will coincidentally decide to withdraw their funds for reasons other than liquidity needs. The liquidity transformation function of banks makes them vulnerable to runs. Bank runs would not be a problem if they were confined to banks that were already (pre-run) insolvent (Gwilym, 2011). According to Gwilym (2011), "a run can in itself causes a bank to default that would not otherwise have defaulted. If enough other depositors are running; it becomes each depositor's best strategy to run them. Any event that causes depositors to anticipate a run also makes them anticipate insolvency. It thus does, in fact, cause a run and so the outcome validates the anticipation. The possibility of a run makes intermediation more costly in terms of depositors needing to monitor banks more closely and banks needing to maintain more reserves. Whereas a bank run relates to an individual bank, a panic refers to a simultaneous run on several banks. If runs are contagious, they will lead to a panic." A bank panic was the case of the banks in Nigeria, before the 2005 bank consolidation exercise, when the banking public lost confidence on 
banks and bank failure became so common.

\section{2 . Empirical Literature}

The empirical stance includes the study by Okoye, Adetiloye, Erin and Evbuomwan (2017). They examined the pre- (9-year period preceding the 2005 banking consolidation exercise) and post- (9-year) consolidation performance of the banking sector of Nigeria. Levene's independent sample t-test was employed by the authors. The findings of the study showed that there was a significant difference in asset quality, capital adequacy ratio and loans and advances ratio. They did not, however, find any significant difference in return on assets, liquidity ratio and bank asset ratio between the pre- and post consolidation periods.

The effect of bank consolidation on the economic growth of Nigeria was examined by Enyinna, Odumegwu and Stanley (2017). The study covered the 2006-2015 sample periods, and the Ordinary Least Square (OLS) technique was employed. The findings of the study showed that commercial bank deposit had a significant positive effect on GDP; while commercial bank asset was found to have no significant effect on real GDP.

Regulatory-induced consolidation through mergers and acquisitions and its implications on banks performance in Nigeria has been examined by Eferakeya and Alagba (2015). Their study scope spans from 2000 to 2010 using eight bank performance ratios consisting of pre-merger and post-merger periods. A descriptive analysis technique was employed for the study. The study revealed that there was no statistically significant improvement change for the profitability, liquidity and leverage performance.

In a study, Olowofeso, Bada, Adeboye, Adejo, Bassey, and Dzaan (2015) examined the dynamics of deposit money banks (DMB) credit and the role of consolidation in credit growth in Nigeria using vector error correction model and Granger causality test. Their study used quarterly data from 1999Q1 - 2013Q2. The authors found a positive relationship between post-consolidation credit supply growth and the real gross domestic product. The authors further pointed out that despite the one-sided positive causality found from credit supply to economic growth the total contribution of the consolidated credit growth to real activity was not significant.

Yakubu (2015) examined the effect of the Nigerian banking consolidation on the country's Economic Growth. The study covered the periods 1980 to 2010. The author adopted Modified Wald (MWALD) test of Granger causality. It was revealed that banking consolidation caused economic growth through loans and advances made by the banks, as expected. However, the interest rate does not cause loans and advances.

Whether the banking industry is really financing capital investment and contributes to the development of the economy were the questions considered by Aruomoaghe and Olugbenga (2014). The study period spans through 1981-2012. The authors found that the banks had contributed much in financing capital investments and stock market development in Nigeria.

Emori, Nkamare, and Nneji (2014) in their study established the impact of bank capital, aggregate investment, loans and advances and bank profitability on the performance of the Nigerian economy. The period of their study spans through 1986-2011 and multiple regression was used for analysis. It was revealed that bank capital was a determinant of banks performance and banks' investment had a positive impact on the economy.

Olayinka and Farouk (2014) examined the impact of consolidation on the performance of banks in Nigeria. The study used a period of 12 years from 2000 to 2011 . The authors studied 22 banks in which four (4) banks were drawn using a stratified sampling technique. They concluded from their study that consolidation had a significant positive impact on the performance of banks in Nigeria.

The study by Nwankwo (2013) analyzed the impact of pre and post bank consolidation on the growth of the Nigerian economy using T-test. It was found that that post bank consolidation had a significant positive effect on the growth of Nigeria economy; pre-bank consolidation had a positive and insignificant effect on economic growth. The author concluded from the results of the study that merger and acquisition growth strategy results in superior economic growth and that pre-bank consolidation are not significant to economic growth.

Obamuyi (2013) examined the extent to which banks in Nigeria had performed their intermediation functions of deposit mobilization and granting of loans and advances and the effects on their performance, from 2006 to 2011. The author used seven selected banks out of the 24 existing banks as a sample. Descriptive statistics of trend analysis, percentage growth and averages were adopted. The results of the study revealed that banks with high deposits and loans performed better in terms of profitability than banks with low deposits and loans.

Barros and Caporale (2012) examined the Nigerian banking consolidation process using a dynamic panel for the period 2000-2010. The Arellano and Bond (1991) dynamic GMM approach was adopted for the study. The authors found that the Nigerian banking sector had benefited from the consolidation process, and specifically that foreign ownership, mergers and acquisitions and bank size decrease costs.

Mogboyin, Asaolu and Ajilore (2011) investigated the response of the flow of credit from the banking sector to reforms and consolidation programmes in the banking sector of Nigeria. The study used cross-sectional data from 89 pre-consolidation banks and 25 post-consolidation banks in Nigeria. The Engle-Granger and error corrections approaches were used. The results of the study revealed that consolidation induced changes in the banking structure in terms of size and capitalization positively influence bank lending performance in the Nigerian 
banking industry.

\section{Methodology}

\subsection{Source of the Data}

The data for this study is collected from the Central Bank of Nigeria Statistical Bulletins 2007 and 2016 and is specifically the data for all the variables outlined in the model specification below. The dataset is an annual time series covering the $1970-2017$.

\subsection{Model Specification}

Model for Bank Consolidation and Banks' credit to the entire economy

The functional form of the model is specified as:

$$
B C E=f(L R, C R R, M P R, \mathrm{Di})
$$

where:

$\mathrm{BCE}=$ Banks' credit to the entire economy

$\mathrm{LR}=$ liquidity ratio

$\mathrm{CRR}=$ Cash reserve ratio

MPR $=\quad$ Monetary policy rate

$\mathrm{D}_{\mathrm{i}}=$ Dummy variable proxy for consolidation policy $(\mathrm{D}=0$ for periods $\quad$ before the 2005 consolidation and 1 for periods after the consolidation)

The econometric model is specified as:

$$
\begin{gathered}
\ln B C E=\varphi_{0}+\varphi_{1} L R+\varphi_{2} C R R+\varphi_{3} M P R+\lambda_{10} D_{i}+\lambda_{11} L R * D_{i}+\lambda_{12} C R R * D_{i}+\lambda_{13} M P R * D_{i} \\
+u_{2} . \quad \text {. } \quad \text { (2) }
\end{gathered}
$$

Where: all variables remain as previously defined

$l n=$ natural logarithm operator

$\varphi_{1}, \varphi_{2}$ and $\varphi_{3}=$ common slope coefficients of LR, CRR and MPR, respectively

$\lambda_{11}, \lambda_{12}$ and $\lambda_{13}=$ differential slope coefficients of LR, CRR and MPR, respectively

$\mathrm{u}_{2}=$ random error term.

Banks' credit to the entire economy (BCE) is logged to bring it to common ratio with LR, CRR, and MPR which are already in rates. The reason for taken the natural logarithm is that logged series effectively linearize exponential trends because the log function is the inverse of an exponential function (Asteriou \& Hall, 2007).

\section{Model for Bank Consolidation and Economic Growth}

The functional form is stated as:

Where:

$$
R G D P=f(L R, I, M P R, \mathrm{Di})
$$

$\begin{array}{lll}\text { RGDP } & = & \text { Real GDP Proxy for economic growth } \\ \mathrm{LR} & = & \text { liquidity ratio } \\ \mathrm{I} & = & \text { investment } \\ \mathrm{MPR} & = & \text { Monetary policy rate } \\ \mathrm{D}_{\mathrm{i}} & = & \text { Dummy variable proxy for consolidation policy }(\mathrm{D}=0 \text { for periods before the } 2005 \text { consolidation }\end{array}$ and 1 for periods after the consolidation)

The econometric model is stated as:

$$
\begin{gathered}
\ln R G D P=\theta_{0}+\theta_{1} L R+\theta_{2} I n I+\theta_{3} M P R+\lambda_{21} D_{i}+\lambda_{22} L R * D_{i}+\lambda_{23} I * D_{i}+\lambda_{24} M P R * D_{i} \\
+u_{2} \quad . \quad \text {. } \quad \text { (4) }
\end{gathered}
$$

Where: all the variables remain as previously defined

ln $=$ natural logarithm operator

$\theta_{1}, \theta_{2}$ and $\theta_{3}=$ common slope coefficients of LR, I \& MPR, respectively

$\lambda_{21}, \lambda_{22}$ and $\lambda_{23}=$ differential slope coefficients of LR, I \& MPR, respectively

$\mathrm{u}_{2}=$ random error term

Banks' credit to the entire economy (BCE) and investment (I) are logged to bring them to common ratio with LR and MPR which are already in rates. The reason for taking the natural logarithm is that logged series effectively linearize exponential trends because the log function is the inverse of an exponential function (Asteriou \& Hall, 2007). The common slope coefficients measure the impact of the explanatory variables, on the dependent variable over time. On the other hand, the differential slope coefficients measure the amount by which the impact of the corresponding explanatory variables on the dependent variables has changed as a result of the 2005 bank consolidation. In other words, the periods of 2005 bank consolidation differ from those before 2005 bank consolidation by $\lambda_{\mathrm{i}}$. If $\lambda_{\mathrm{i}}>0$, then the period after consolidation has a larger coefficient than the period before the policy; and the impact of the consolidation policy is positive. Whereas if $\lambda_{\mathrm{i}}<0$ the reverse is the case and if $\lambda_{\mathrm{i}}=$ 0 , then there is no difference between the coefficients for both periods and the policy has no (zero) impact on the dependent variable(s). 


\subsection{Estimation Techniques}

Estimation proceeds with a test for multicollinearity to confirm the explanatory variables are to some degree, free from linear dependency. The Augmented Dickey-Fuller (ADF) unit root test shall also be conducted. If all the variables become stationary of the same order, say order one, I(1) the Johansen's Cointegration test shall be adopted to test for a long-run relationship. But if the variables are not integrated of the same order, that is, regressors are a mixture of $\mathrm{I}(0)$ and $\mathrm{I}(1)$ variables; the bounds testing approach is the relevant test for cointegration.

\section{Results}

\subsection{Test for multicollinearity}

The variables in the specified two models to capture objectives one and two were subjected to multicollinearity test. This test is necessary in order to avoid the consequences of multicollinearity and to obtain unique estimates of the regression parameters. The test results are presented as shown below:

Table 1: Variance inflation factors (VIFs) for all the variables in equation (2)

\begin{tabular}{c|cc}
\hline Variables & VIF & $\mathbf{1 / V I F}$ \\
\hline MPR & 1.18 & 0.848245 \\
CRR & 1.13 & 0.881630 \\
LR & 1.17 & 0.856793 \\
\hline Mean VIF & 1.16 & \\
\hline
\end{tabular}

Source: Author's Computation

Table 2: Variance inflation factors (VIFs) for all the variables in equation (4)

\begin{tabular}{l|cc}
\hline Variables & VIF & $\mathbf{1 / V I F}$ \\
\hline MPR & 2.67 & 0.374443 \\
GFCF & 2.88 & 0.346810 \\
LR & 1.21 & 0.825142 \\
\hline Mean VIF & 2.26 & \\
\hline
\end{tabular}

Source: Author's Computation

The variables included in the two regression equations to capture objectives one and two are all free from the problem of multicollinearity. As shown in tables 4.1 and 4.2, the Variance Inflation Factors (VIFs) of all variable in the two regression equations are very low. They are all below the conventional 10. This indicates that the inclusion of Monetary Policy Rate (MPR), Cash Reserve Ratio (CRR), and Liquidity ratio in our regression equation for objective one will not affect the uniqueness of the regression parameter estimates. Thus the above variables shall be included as explanatory variables in our regression equation to explain the dependent variable. Similarly, MPR, LR, and Gross Fixed Capital Formation (GFCF) shall be included in the regression equation for objective two to explain the dependent variable.

\subsection{Augmented Dickey-Fuller Unit Root Test}

Again, to avoid the problem of spurious results that usually occurs due to non-stationary data, we conduct a test for stationarity.

Table 3: Results of Unit Root Test using Augmented Dickey-Fuller Test Procedure

\begin{tabular}{cccc|cccc}
\hline Variable & \multicolumn{3}{c|}{ At level } & \multicolumn{3}{c}{ First Difference } \\
\cline { 2 - 7 } & $\begin{array}{c}\text { No } \\
\text { Constant }\end{array}$ & Constant & $\begin{array}{c}\text { Constant } \\
\text { \& trend }\end{array}$ & $\begin{array}{c}\text { No } \\
\text { constant }\end{array}$ & Constant & $\begin{array}{c}\text { Constant \& } \\
\text { trend }\end{array}$ & $\begin{array}{c}\text { Lag } \\
\text { length }\end{array}$ \\
\hline BCE & 0.109 & -1.946 & -1.341 & $-6.917 * * *$ & $-6.878^{* * *}$ & $-7.085 * * *$ & 1 \\
RGDP & -0.688 & -1.726 & -1.706 & $-6.246 * * *$ & $-6.184 * * *$ & $-6.150 * * *$ & 1 \\
MPR & -0.308 & -1.821 & -1.750 & $-3.967 * * *$ & $-3.966 * * *$ & $-4.042 * *$ & 1 \\
CRR & -1.082 & $-2.619 *$ & -2.914 & $-3.842 * * *$ & $-3.795^{* * *}$ & $-3.731 * *$ & 1 \\
LR & -1.136 & $-3.590^{* *}$ & $-3.628^{* *}$ & $-6.771 * * *$ & $-6.715^{* * *}$ & $-6.671 * * *$ & 1 \\
GFCF & -1.437 & -1.767 & -1.172 & $-6.290^{* * *}$ & $-6.304 * * *$ & $-6.483 * * *$ & 1 \\
\hline
\end{tabular}

Where: $* * *, * *$, and $*$ denotes significance at $1 \%, 5 \%$ and $10 \%$ respectively and the rejection of the null hypothesis of the presence of unit root. The optimal lag lengths were chosen according to Akaike's FPE tests.

Source: Authors Computation

The Augmented Dickey-Fuller test results revealed that the variables are all stationary at first difference at 5\% level except Liquidity Ratio (LR) which is stationary at levels. This result also indicates the possibility of cointegration of the variables. Therefore in the next section, a test for cointegration is carried out.

\subsection{Johansen Cointegration Test}

The study conducts a cointegration test to establish if a long run relationship exists among the variables of interest. To achieve this, we use the trace statistics to compare with the 5\% critical value. The results are as follows: 
Table 4: Results of Johansen test for cointegration between BCE, MPR, CRR and LR

\begin{tabular}{cccc}
\hline $\begin{array}{c}\text { Maximum } \\
\text { Rank }\end{array}$ & Eigenvalue & Trace Statistics & 5\% critical value \\
\hline 0 & & 46.2587 & 39.89 \\
1 & 0.45833 & $20.5084^{*}$ & 24.31 \\
2 & 0.33176 & 3.5776 & 12.53 \\
3 & 0.08162 & 0.0017 & 3.84 \\
4 & 0.00004 & - & - \\
\hline
\end{tabular}

Source: author's computation

Table 5: Results of Johansen test for cointegration between RGDP, MPR, LR and GFCF

\begin{tabular}{cccc}
$\begin{array}{c}\text { Maximum } \\
\text { Rank }\end{array}$ & Eigenvalue & Trace Statistics & 5\% critical value \\
\hline 0 & & & 54.64 \\
1 & 0.38927 & 57.5088 & 34.55 \\
2 & 0.30768 & $11.3550 *$ & 18.17 \\
3 & 0.19227 & 2.3870 & 3.74 \\
4 & 0.05525 & - & - \\
\hline
\end{tabular}

Source: author's computation

The tests show the existence of cointegration between the dependent variable and the independent variables in all the two regression equations. The first equation shows the existence of one cointegrating equation as shown in table $4.4 \mathrm{a}$, while table $4.4 \mathrm{~b}$ revealed the existence of two cointegrating equations.

\subsection{The Impact of Bank Consolidation on Deposit Money Banks' Credit to the Nigerian Economy}

To examine the impact of bank consolidation policy on banks credit to the economy, we regress BCE on Monetary Policy Rate (MPR), Cash Reserve Ratio and Liquidity Ratio. The regression results are presented in table 4.6. For the period before the consolidation policy, the result revealed that MPR and CRR have a positive relationship with BCE, while LR has a negative relationship.

Table 6: Results of the impact of bank consolidation policy on banks credit to the economy

\begin{tabular}{|c|c|c|c|c|}
\hline $\mathrm{BCE}$ & coefficients & $\begin{array}{c}\text { Robust } \\
\text { Standard Errors }\end{array}$ & t-statistics & P-value \\
\hline MPR & 0.3369253 & 0.0804503 & 4.19 & 0.000 \\
\hline CRR & 0.0748218 & 0.0414757 & 1.80 & 0.080 \\
\hline LR & -0.0254681 & 0.0153581 & -1.66 & 0.106 \\
\hline $\mathrm{Di}$ & -4.982586 & 2.85018 & -1.75 & 0.089 \\
\hline DiMPR & 1.363026 & 0.4834727 & 2.82 & 0.008 \\
\hline DiCRR & -0.4893345 & 0.1685458 & -2.90 & 0.006 \\
\hline DiLR & -0.1230929 & 0.0806802 & -1.53 & 0.136 \\
\hline Constant & 7.184974 & 1.38978 & 5.17 & 0.000 \\
\hline \multicolumn{5}{|c|}{0.6594} \\
\hline \multicolumn{2}{|c|}{ Adjusted R-squared } & \multicolumn{2}{|l|}{0.5913} & \\
\hline F-statistics & $\mathrm{F}(7,35)$ & \multicolumn{2}{|l|}{9.68} & \\
\hline Durbin-Watson & d-statistic $(8,43)$ & \multicolumn{2}{|c|}{0.8363288} & \\
\hline Breusch-Godfr & -square Statistics & \multicolumn{2}{|c|}{$17.206(0.0000)$} & \\
\hline Ramsey RESET & 32) & \multicolumn{2}{|c|}{$1.51(0.2630)$} & \\
\hline LM heterosked & ii-square Statistics & \multicolumn{2}{|c|}{$0.324(0.5694)$} & \\
\hline
\end{tabular}

Source: Author's computation

A percentage increase in MPR and CRR increased BCE by 33.69 and 7.48 per cent respectively. On the other hand, a percentage increase in LR reduces the BCE by 2.55 per cent. During the period of the bank consolidation policy proper, BCE was affected negatively. BCE reduced by over 100 per cent. After the policy, however, the sign for CRR changed. A percentage increase in CRR reduces BCE by $48.93 \%$. This result came out in accordance with expectation. Similar signs with the period before bank consolidation were observed after the policy for the variables MPR and LR. But the impact on BCE was lager after the policy. It revealed that after the policy, a percentage increase in MPR increases BCE by over 100\%, while a percentage increase in LR reduces BCE by $12.3 \%$. The reduction in BCE caused a percentage increase in LR after the policy is $9.8 \%$ higher. This change is characterized by the policy. This showed that the liquidity ratio and the cash reserve ratio after the policy has not benefited the economy in terms of credit availability. Likewise the cash reserve ratio. Though LR is not statistically significant before and after the policy, the CRR is statistically significant after the consolidation and insignificant 
before the policy. The MPR, on the other hand, is significant both before and after the consolidation.

The differential intercepts and slopes were together statistically significant as the F-statistics with 7 and 35 degrees of freedom of 9.68 is greater than the 2.84 critical value at $5 \%$. The study, therefore, rejects the hypothesis that banks' consolidation has no significant impact on the performance of the Nigerian economy and concludes that the 2005 bank consolidation policy has a significant impact on banks credit to the entire economy of Nigeria. That is, in all the variables we reject the test hypotheses except liquidity ratio which has no differential impact on the performance of the economy before and after the policy. The findings in this study are similar to the findings of the study of Basu, Druck, Marston, and Susmel (2004) in Argentina who examines the effects of bank consolidation on bank performance for more than 100 banks and found a significant effect of bank consolidation on banks performance. It is also similar to the findings of Joshua (2010) in Nigeria who found that banks' consolidation has a significant impact on banks' efficiency and the capital market performance.

The Durbin-Watson statistics of 0.8363288 indicates a zone of indecision. Thus the presence or absence of autocorrelation could not be ascertained. That notwithstanding, the Breusch-Godfrey LM Chi-square Statistics of 17.206 (0.0000) showed strong evidence of serial correlation (see table B5 of the appendix). The results were however robust since the standard errors were corrected for arbitrary level of serial correlation. The Ramsey RESET test statistics of $1.51(0.2630)$, which is statistically insignificant implies the rejection of the hypothesis that the model is incorrectly specified. Thus the model in this study is correctly specified. Finally, the LM heteroskedasticity Chi-square Statistics of $0.324(0.5694)$ means that the model is free from heteroskedasticity.

\subsection{Impact of Bank Consolidation on Economic Growth in Nigeria}

The results are presented in table 4.6. The results revealed that before the consolidation policy, Monetary Policy Rate (MPR), Liquidity Ratio (LR) and Investment (gross fixed capital formation, GFCF) positively impacted on economic growth in Nigeria. After the consolidation, however, LR turned out to impact economic growth negatively.

Table 4.7: Results of the impact of bank consolidation on economic growth

\begin{tabular}{|c|c|c|c|c|}
\hline $\begin{array}{l}\text { Dependent } \\
\text { Variables }\end{array}$ & coefficients & $\begin{array}{c}\text { Robust } \\
\text { Standard Errors }\end{array}$ & t-statistics & P-value \\
\hline MPR & 0.0133662 & 0.0128279 & 1.04 & 0.305 \\
\hline GFCF & 0.7928894 & 0.2582914 & 3.07 & 0.004 \\
\hline LR & 0.013798 & 0.0070174 & 1.97 & 0.057 \\
\hline $\mathrm{Di}$ & 0.7732662 & 0.7515631 & 1.03 & 0.311 \\
\hline DiMPR & 0.0540029 & 0.0411841 & 1.31 & 0.199 \\
\hline DiGFCF & 0.0005754 & 0.0025342 & -3.23 & 0.822 \\
\hline DiLR & -0.0285287 & 0.0146544 & -2.95 & 0.060 \\
\hline Constant & -0.6327841 & .3283695 & -1.93 & 0.062 \\
\hline \multicolumn{2}{|l|}{$\mathrm{R}^{2}$} & \multicolumn{2}{|l|}{0.7170} & \\
\hline \multicolumn{2}{|c|}{ Adjusted R-squared } & \multicolumn{2}{|l|}{0.6587} & \\
\hline F-statistics & $\mathrm{F}(7,35)$ & \multicolumn{2}{|l|}{12.31} & \\
\hline Durbin-Watson & d-statistic $(8,43)$ & \multirow{2}{*}{$\begin{array}{l}1.937419 \\
0.038(0.8\end{array}$} & & \\
\hline Breusch-Godfre & -square Statistics & & $0.038(0.8445)$ & \\
\hline Ramsey RESET & 32) & \multicolumn{2}{|c|}{$0.56(0.3160)$} & \\
\hline LM heteroskeda & i-square Statistics & \multicolumn{2}{|c|}{$0.024(0.8770)$} & \\
\hline
\end{tabular}

Source: Author's Computation

For the period before the consolidation, a percentage increase in MPR, GFCF, and LR leads to an increase in real economic growth by $1.34 \%, 79.29 \%$ and $1.38 \%$ respectively. Even at the period of the consolidation proper, the economic growth rate witnessed a $77.32 \%$ increase resulting from the policy.

During the period after the policy, it is revealed that a percentage increase in MPR and GFCF boost economic growth by 5.40 and 0.05 per cent. There is an improvement in economic growth percentage by 4.06 per cent due to the percentage increase in MPR after the consolidation. But the case of GFCF is different as economic growth reduces by 79.29percent compared to the period before the consolidation policy. On the other hand, 2.85 per cent reduction was witnessed for every percentage point increase in gross capital formation. This, however, negates our expectation.

Again, the differential intercepts and slopes are jointly statistically significant as the F-statistics with 7 and 35 degrees of freedom of 12.31 is greater than the critical value of 2.18 . Based on this, the study generally rejects the hypothesis and concludes that the bank consolidation policy has a significant impact on economic growth in Nigeria. Specifically, however, the hypotheses that gross capital formation and liquidity ratio has no significant impact on economic growth after the consolidation policy is rejected while the hypotheses that monetary policy rate has no significant impact on economic growth after the consolidation is accepted. This finding is consistent with the findings of Nwankwo (2013) in Nigeria who analyzed the impact pre and post bank consolidation on the 
growth of the Nigerian economy and found post bank consolidation to had a significant effect on the growth of the Nigerian economy; an insignificant effect was found for the period before the consolidation policy. Also, Yakubu (2015) in Nigeria had similar findings with the findings of this study. They found that banking sector consolidation causes economic growth.

Durbin-Watson statistics d-statistic of 1.937419 showed no autocorrelation, likewise, the Breusch-Godfrey LM Chi-square Statistics of $0.038(0.8445)$ showed an evidence that there is no serial correlation. The Ramsey RESET F-statistics showed a value of 0.56 (0.3160). Based on this insignificant value, we accept the null hypothesis and conclude that the model for this study is correctly specified. Finally, an insignificant LM heteroskedasticity Chi-square Statistics of $0.024(0.8770)$ is an indication of the acceptance of the null hypothesis. Thus there is no problem of heteroskedasticity. That is, the variables of the study have constant (equal) variance.

\section{Conclusions}

The study examined the relationship between bank consolidation and performance of Nigeria's economy. The variables selected for the study were bank credit to the entire economy, and real GDP as dependent variables, while monetary policy rate, cash reserve ratio, liquidity ratio, and gross capital formation proxy for investment are explanatory variables. Bank consolidation had a significant impact on banks' credit to the entire economy and economic growth in Nigeria. This study had provided an insight into the contributions of banks consolidations to the Nigerian economy by revealing that compared to the pre-consolidation era; the economy had performed better after the banks' consolidation policy.

It recommends that consolidation policy should be carried out periodically in order for banks and the entire banking sector to come out stronger. Also, the credibility of the banking sector authority is also relevant. Thus the study recommends the use of highly qualified personnel for the formulation of banking sector policies.

\section{References}

Adeyemi, K. S. (2006). Banking Sector Consolidation in Nigeria: Issues and Challenges. Position Paper No. 54 Anyanwu, C.M. (2010). An Overview of Current Banking Sector Reforms and the Real Sector of the Nigerian Economy. CBN Economic and Financial Review, 48/4: 24

Aruomoaghe, J. A. and Olugbenga, E. (2014). Financing Capital Investments in Nigeria: The Role of the Banking Industry. Asian Economic and Financial Review, 4(8), 1123 - 1130

Asteriou, D. and Hall, S. (2007). Applied Econometrics. New York: PalGrave Macmillan

Baily, M. N. and Elliott, D. J. (2013). The Role of Finance in the Economy: Implications for Structural Reform of the Financial Sector. The Brookings Institution.

Balogun, E. D. (2007). Banking Sector Reforms and the Nigerian Economy: Performance, Pitfalls, and Future Policy Options. MPRA Paper No. 3804 Available at http://mpra.ub.uni-muenchen.de/3804/

Barros, C. P. and Caporale, G. M. (2012). Banking Consolidation in Nigeria. Mais Working Papers No. 99. Available at: http://pascal.iseg.utl.pt/ cesa/index.php/menupublicacoes/working-papers

Basu, R., Druck, P., Marston, D. and Susmel, R. (2004). Bank Consolidation and Performance: The Argentine Experience. IMF Working Paper No. 04/149.

Central Bank of Nigeria (2016). Central Bank of Nigeria Statistical Bulletin. Abuja-Nigeria: CBN Publications Central Bank of Nigeria (2009). Central Bank of Nigeria Statistical Bulletin. Abuja-Nigeria: CBN Publications CBN (2004), Central Bank of Nigeria Annual Report and Statement of Accounts. Abuja: CBN Publications

Eferakeya, I. and Alagba, O. S. (2015). Regulatory-induced consolidation through mergers and acquisitions and its implication on banks performance in Nigeria. International Journal of Business and Industrial Marketing, $1(1), 6-15$

Emori, E., Nkamare, S. and Nneji, I. (2014). The Impact of Banking Consolidation on the Economic Development of Nigeria. Research Journal of Finance and Accounting, 5(16), 113 - 119

Enyinna, U. K., Odumegwu, O. I. and Stanley, K. A. (2017). Evaluation of the Effect of Commercial Bank Consolidation on Economic Growth (Evidence from Nigeria, 2006- 2015). Management Studies and Economic Systems, 3(2), 61-75.

Gwilym, O. A. (2011). Financial Intermediation. Undergraduate Study in Economics, Management, Finance and the Social Sciences. The London School of Economics and Political Science. Available at: www.londoninternational.ac.UK

Iganiga, B. O. (2010). Evaluation of the Nigerian Financial Sector Reforms using Behavioral Models. Journal of Economics, 1(2), 65 - 75

Joshua, O. (2010). Comparative Analysis of the Impact of Mergers and Acquisitions on Financial Efficiency of Banks in Nigeria. Journal of Accounting and Taxation, 3(1), 1 - 7

Mogboyin, O., Asaolu, T. O. and Ajilore, O. T. (2011). Bank Consolidation Programme and Lending Performance in Nigerian Banking System: An Empirical Analysis with Panel Data. International Journal of Applied Economics and Finance, 3, 1 - 9. 
Nwankwo, O. F. (2013). Impact of Pre and Post Bank Consolidation on the Growth of Nigeria Economy. International Journal of Business and Management, 8(13), 73 - 82

Obamuyi, T. M. (2013). Analysis of the Deposits and Lending Behaviors of Banks in Nigeria. International Journal of Engineering and Management Sciences, 4(1), 46 - 54

Ohale, L. and Onyema, J. I. (2002). Foundations of Macroeconomics. Owerri: Springfield Publishers.

Okoye, L. U., Adetiloye, K. A., Erin, O. and Evbuomwan, G. O. (2017). Impact of Banking Consolidation on the Performance of the Banking Sector in Nigeria. Journal of Internet Banking and Commerce, 22(1), 2 - 16.

Olayinka, T. T. and Farouk, M. A. (2014). The Impact of Consolidation on the Performance of Banks in Nigeria. Global Advanced Research Journal of Management and Business Studies, 3(10), 479 - 485

Olowofeso, O. E., Bada, A. S., Adeboye, A. A., Adejo, V. T., Bassey, K. J. and Dzaan, K. S. (2015), Investigating the Dynamics of Bank Credit in Nigeria: The Role of Bank Consolidation. CBN Journal of Applied Statistics, 6(1a), 133-151

Omoruyi, S. E. (1991). The Financial Sector in Africa: Overview and Reform in Economic Adjustment Programmes. CBN Economic and Financial Review, 29(2), 100 - 124.

Sanusi, L.S. (2010), The Nigerian Banking Industry: What went wrong and the Way Forward. A Lecture Delivered at the Annual Convocation Ceremony of the Bayero University, Central Bank of Nigeria.

Waheed, A. (2009). Financial Sector Reforms and Economic Growth: A Time Series Data Analysis for Pakistan. Japan Institute of Development Economics Working Paper No.452

Yakubu, Y. (2015). Banking Consolidation and Economic Growth in Nigeria: Dynamic Chain Transmission Evidence. IOSR Journal of Humanities and Social Science, 20(5), 27 - 33 